\title{
Efektivitas Campuran Ekstrak Daun Srikaya (Annona squamosal L.) dan Rimpang Kunyit (Curcuma domestica Val.) pada Mortalitas Larva Spodoptera litura F. (Lepidoptera: Noctuidae)
}

\section{(The Efficacy of Mixed Extract of Sweetsop Leaves (Annona squamosa L.) and Turmeric Rhizomes (Curcuma domestica Val.) on Mortality of Spodoptera litura F. Larvae (Lepidoptera: Noctuidae))}

\author{
Ramadhan Taufika*, Setyo Andi Nugroho, Anni Nuraisyah
}

(Diterima Februari 2020/Disetujui Oktober 2020)

\begin{abstract}
ABSTRAK
Larva Spodoptera litura F. (Lepidoptera: Noctuidae) merupakan serangga polifagus yang menyebabkan kerusakan pada jenis tanaman perkebunan, hortikultura, dan pangan sehingga perlu dilakukan upaya pengendalian. Salah satu cara pengendalian yang ramah lingkungan untuk menjaga keseimbangan ekologi adalah penggunaan insektisida nabati yang senyawa bioaktifnya berasal dari ekstrak tanaman. Penelitian ini menggunakan campuran dua ekstrak tanaman yang berasal dari ekstrak daun $A$. squamosa dan rimpang $C$. domestica (campuran ekstrak uji). Kedua campuran ekstrak uji bersifat sinergis sehingga lebih efektif dan memerlukan konsentrasi yang lebih rendah pada mortalitas larva $S$. litura daripada penggunaan ekstrak tunggal. Tujuan penelitian adalah untuk mengetahui

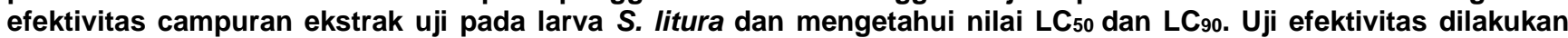
dengan metode celup pakan ke dalam campuran ekstrak uji. Data mortalitas dianalisis dengan ANAVA, selanjutnya uji lanjut Duncan dengan taraf kepercayaan 95\% dan analisis Probit untuk penentuan LC s0 $_{50}$ LC 90 . Hasil perhitungan menunjukkan bahwa nilai LC 50 campuran ekstrak uji pada larva instar kedua dan ketiga secara berurut adalah 5.252 ppm dan 10.559 ppm serta LC 90 secara berurut adalah 11.124 ppm dan 13.638 ppm. Berdasarkan penelitian tersebut disimpulkan bahwa campuran ekstrak uji efektif pada mortalitas larva $S$. litura dan campuran ekstrak uji lebih efektif pada mortalitas larva instar kedua daripada larva instar ketiga S.litura. Dengan demikian, campuran ekstrak uji tersebut bisa dikembangkan lebih lanjut dalam skala lapang terbatas (green house) untuk menguji keefektifannya pada mortalitas larva S. litura yang nantinya bisa digunakan sebagai alternatif pengendalian larva S. litura yang ramah lingkungan di kalangan petani organik maupun konvensional.
\end{abstract}

Kata kunci: ekstrak, mortalitas, pengendalian, Spodoptera litura

\section{ABSTRACT}

Spodoptera litura F. larvae (Lepidoptera: Noctuidae) are polyphagous insects that cause damages to many types of plantations and horticulture that need to be protected. One of environmentally friendly method to protect ecological balance is the use of botanical insecticides whose bioactive compounds come from plant extracts. This study used a mixture of two plant extracts from $A$. squamosa leaves extract and $C$. domestica rhizome exstract (the mixed of experimental extracts). The mixed of experimental extracts are synergistic so that they are more effective and need a lower concentration to cause the mortality of $S$. litura larvae than the use of a single extract. The aims of the research were to know the efficacy of the mixed of experimental extracts on the mortality of S. litura larvae and determine the value of $\mathrm{LC}_{50}$ and $\mathrm{LC}_{90}$ extract test on its mortality. The initial and efficacy test were conducted by bait dip into the mixed of experimental extracts. The mortality data were analyzed using ANAVA, then continued by Duncan test and Probit analysis. The results of this research showed that the mixed of experimental extracts were effective to kill $S$. litura larvae. The calculated result of $L_{50}$ and $L_{5} C_{90}$ showed that the $L_{50}$ value of the experimental extracts on the second and the third instar larvae were $5.252 \mathrm{ppm}$ and $10.559 \mathrm{ppm}$, respectively, and the LC 90 value for both instar larvae were $11.124 \mathrm{ppm}$ and $13.638 \mathrm{ppm}$, respectively. It could be concluded that the mixed of experimental extracts is effective in S. litura larvae mortality and more effective in the mortality of the second instar larvae than that of the third instar larvae. Therefore, this test extract mixture can be developed further in a greenhouse to evaluate the effectiveness in the mortality of $S$. litura larvae which can be used as an alternative to controlling $S$. litura larvae with an environmentally friendly material in farmers.

Keywords: control, extract, mortality, Spodoptera litura

Politeknik Negeri Jember, Jalan Mastrip Kotak Pos 164 Jember 68101

* Penulis Korespondensi:

Email: ramadhantaufika@polije.ac.id

\section{PENDAHULUAN}

Larva Spodoptera litura Fabricius (Lepidoptera: Noctuidae) merupakan serangga polifagus yang 
menyebabkan kerusakan pada berbagai jenis tanaman perkebunan, hortikultura, dan pangan (Kalshoven 1981; Shahout et al. 2011; Rao et al. 2014; Kumar and Sevarkodiyone 2009; Selvaraj et al. 2010). Sebagian besar daerah di Indonesia pernah dilaporkan mengenai kejadian kerusakan tanaman pertanian yang disebabkan oleh populasi larva S. litura. Kerusakan pertanian sawi, tembakau, dan kubis di Indonesia pada tahun 2013 akibat populasi larva S. litura mencapai $80 \%$, bahkan di Provinsi Jawa Barat, Jawa Tengah, dan Jawa Timur mencapai 100\% (Marwoto \& Suharsono 2008). Oleh karena itu, untuk mengurangi kerusakan tanaman pertanian dan meningkatkan produksi hasil pertanian di Indonesia maka perlu dilakukan pengendalian populasi larva $S$. litura untuk menekan jumlah populasi supaya berada di bawah nilai ambang ekonomi.

Pengendalian populasi larva $S$. litura yang dilakukan oleh petani di Indonesia pada umumnya masih menggunakan insektisida yang berasal dari senyawa kimia sintetis (Balfas \& Willis 2009). Penggunaan insektisida kimia bagi kalangan petani di Indonesia masih dianggap sebagai salah satu cara pengendali populasi Organisme Pengganggu Tanaman (OPT) secara cepat dan efektif (Hasibuan 2015). Penggunaan insektisida kimia terus-menerus dalam jangka waktu yang lama memiliki banyak kelemahan, yakni menyebabkan resistensi hama, kematian organisme non-target, kehadiran residu yang berdampak pada kesehatan manusia, persisten di lingkungan, dan berdampak negatif bagi lingkungan, yakni menimbulkan pencemaran air, udara, dan tanah (Felsot \& Racke 2007; Kandagal \& Khetagoudar 2013; Hasibuan 2015; Soemirat \& Ariesyady 2015). Suryaningsih \& Hadisoeganda (2004) menyatakan bahwa penggunaan insektisida kimia untuk pengendali populasi OPT hanya sekitar $30 \%$ mengenai organisme target, sedangkan $70 \%$ insektisida terbuang ke lingkungan.

Peningkatan produk pertanian yang bebas dari residu insektisida penting dilakukan untuk mewujudkan kedaulatan pangan yang bebas dari insektisida kimia, salah satunya adalah dengan menggunakan bahan bioaktif yang berasal dari ekstrak organ tanaman atau biasa dikenal sebagai insektisida nabati. Beberapa keunggulan penggunaan insektisida nabati ialah ramah lingkungan, bahan mudah diperoleh, tidak menimbulkan resistensi pada serangga hama, tidak toksik pada serangga nontarget, tidak persisten di lingkungan, menghasilkan produk pertanian yang bebas residu insektisida kimia, serta caranya mudah dan murah untuk diterapkan langsung oleh petani (Sutoyo \& Wiriadmojo 1997; Liu et al. 2010; Singh \& Saratchandra 2005; Kumar \& Sevarkodiyone 2009; Selvaraj et al. 2010; Selvaraj et al. 2010).

Dua jenis tanaman yang dapat dimanfaatkan sebagai bahan insektisida nabati adalah tanaman srikaya (Annona squamosa Linnaeus), yakni organ daun dan biji serta tanaman kunyit (Curcuma domestica Valeton), yakni organ rimpang. Hasil penelitian Rimbawani (2009) dan Mulyaman et al.
(2000) menyatakan bahwa daun dan biji $A$. squamosa mengandung senyawa bioaktif yang disebut acetogenin, yang merupakan kelompok senyawa alkaloid yang efektif dalam menyebabkan mortalitas larva $S$. litura. Senyawa bioaktif yang terdapat pada rimpang $C$. domestica adalah ar-tumeron yang merupakan kelompok senyawa sesquiterpen dan flavonoid yang diduga berpotensi sebagai bahan aktif insektisida (Zhang et al. 2008). Hasil penelitian Lee et al. (2001) menunjukkan bahwa ekstrak metanol rimpang $C$. domestica pada konsentrasi 250 ppm menyebabkan $52 \%$ mortalitas larva Plutella xylostella. Tavares et al. (2013) melaporkan ekstrak hexan $C$. domestica pada konsentrasi 10.000 ppm menyebabkan 58\% mortalitas larva Spodoptera frugiperda. Hasil penelitian Balfas \& Willis (2009) menunjukkan bahwa ekstrak metanol C. domestica pada konsentrasi 10.000 ppm menyebabkan 20\% mortalitas larva $S$. litura.

Penggunaan ekstrak tanaman sebagai insektisida nabati dapat dilakukan secara tunggal dan campuran. Penggunaan ekstrak tunggal sebagai insektisida nabati memiliki kelebihan karena ekstrak tunggal tidak memiliki sifat sinergis dan antagonis. Campuran ekstrak tanaman dapat bersifat antagonis maupun sinergis. Campuran dua ekstrak tanaman yang bersifat antagonis dapat menurunkan efektivitas suatu insektisida nabati pada serangga hama daripada penggunaan ekstrak tunggal. Sebaliknya, campuran dua ekstrak tanaman atau lebih yang bersifat sinergis akan meningkatkan efektivitas suatu insektisida pada serangga hama daripada penggunaan ekstrak tunggal (Koul \& Walia 2009). Menurut Vastrad et al. (2002), campuran dua ekstrak tanaman yang memiliki senyawa bioaktif yang bersifat sinergis lebih efektif sebagai agensia pengendali serangga hama dan vektor penyakit daripada ekstrak tunggal. Hasil penelitian Dadang et al. (2011) menunjukkan bahwa campuran ekstrak daun Piper retrofractum dan biji $A$. squamosa dengan konsentrasi 1.000 ppm efektif untuk mengurangi populasi larva Plutella xylostella dan Crocidolomia pavonana daripada menggunakan ekstrak tunggal. Sumber yang sama menyebutkan bahwa campuran ekstrak biji $A$. squamosa dan daun Aglaia odorata lebih efektif untuk mengurangi populasi larva $C$. pavonana daripada menggunakan ekstrak tunggal.

Efektivitas campuran ekstrak daun $A$. squamosa dan rimpang $C$. domestica sebagai insektisida nabati belum pernah diaplikasikan pada larva $S$. litura sehingga perlu dilakukan penelitian tentang efektivitas campuran ekstrak daun $A$. squamosa dan rimpang $C$. domestica. Dengan demikian, diharapkan campuran ekstrak daun $A$. squamosa dan rimpang $C$. domestica bisa dikembangkan lebih lanjut dalam skala lapang terbatas (green house) untuk menguji keefektifannya pada mortalitas larva $S$. litura yang nantinya bisa digunakan sebagai alternatif pengendalian larva $S$. litura yang ramah lingkungan di kalangan petani konvensional dan organik. 


\section{METODE PENELITIAN}

\section{Bahan dan Alat}

Bahan utama yang digunakan dalam penelitian ini adalah larva $S$. litura yang diperoleh dari ladang sawi di Desa Ketep, Kecamatan Sawangan, Kabupaten Magelang, daun $A$. squamosa yang diperoleh dari Perkebunan "Sabila Farm" JIn. Kaliurang Km 18,5 Kecamatan Pakem, Kabupaten Sleman, dan rimpang C. domestica. Bahan pembuatan pakan buatan larva S. litura meruppakan modifikasi dari formulasi Poitout et al. (1972) dengan komposisi aquadest steril, asam benzoat, sari agar-agar Tan Tjoen Yoe, asam askorbat, tepung jagung Maizena, ragi roti Gist, dan tepung gandum Quaker Oat. Larutan madu 10\% sebagai pakan imago. Pelarut yang digunakan untuk ekstraksi adalah etanol $96 \%$. Bahan pembuatan larutan stok dan pengenceran untuk uji pendahuluan dan efektivitas adalah aqudest, kontrol positif berupa insektisida Dipel WP, bahan aktif Bacillus thuringiensis strain kurstaki konsentrasi 5.000 ppm serta kontrol negatif berupa larutan etanol $1 \%$.

Alat yang digunakan dalam penelitian ini adalah toples plastik ukuran diameter $15 \times 20 \mathrm{~cm}$, kuas lukis nomor 4 dan pinset, toples kaca diameter $14 \times 22 \mathrm{~cm}$, toples plastik diameter $14 \times 5 \mathrm{~cm}$, botol plastik diameter $3,5 \times 4 \mathrm{~cm}$, panci diameter $17 \times 7,5 \mathrm{~cm}$, nampan plastik ukuran $22 \times 16,5 \times 4 \mathrm{~cm}$, blender Philips kapasitas 1,5 $\mathrm{L}$, oven listrik Memmert kapasitas suhu $70^{\circ} \mathrm{C}$, timbangan semi analitik Mini Digital Scale kapasitas $200 \mathrm{~g}$, gelas ukur pyrex $500 \mathrm{~mL}$, toples kaca kapasitas $10 \mathrm{~L}$ dan $3 \mathrm{~L}$, batang pengaduk kaca panjang $30 \mathrm{~cm}$, corong kaca, erlenmeyer pyrex $1000 \mathrm{~mL}$, mangkuk kaca kapasitas $1 \mathrm{~L}$, gelas kaca diameter $3 \times 6 \mathrm{~cm}$, almari kaca ukuran $70 \times 70 \times 70 \mathrm{~cm}$, kipas angin Natex diameter $30 \mathrm{~cm}$, serta kamera Canon Ixus $275 \mathrm{HS}$. Alat yang digunakan untuk uji pendahuluan dan efektivitas adalah higrotermometer, botol plastik diameter 3,5 x 4 $\mathrm{cm}$, serta glass jam diameter $6 \times 9 \mathrm{~cm}$.

\section{Lokasi Penelitian}

Pemeliharaan larva $S$. litura, pembuatan ekstrak daun $A$. squamosa dan rimpang $C$. domestica, uji pendahuluan, serta uji efektivitas dilakukan di Laboratorium Entomologi, Fakultas Biologi, Universitas Gadjah Mada.

\section{Metode/cara pengumpulan data \\ - Pemeliharaan S. litura}

Sebanyak 115 larva instar kedua dan ketiga S. litura diperoleh dari perkebunan sawi di Desa Ketep, Kecamatan Sawangan, Kabupaten Magelang. Pengambilan larva $S$. litura dilakukan dengan menggunakan pinset dan kuas lukis nomor 4 secara berhati-hati, agar tidak merusak struktur tubuh larva $S$. litura. Larva $S$. litura dimasukkan ke dalam toples plastik berdiameter $15 \times 20 \mathrm{~cm}$ yang tutupnya dimodifikasi menggunakan kain kasa. Larva yang diperoleh dari perkebunan sawi dipelihara di Laboratorium Entomologi, Fakultas Biologi, Universitas Gadjah Mada. Larva yang diperoleh dari perkebunan sawi diaklimatisasi terlebih dahulu selama 1 hari di Laboratorium. Satu larva dimasukkan ke dalam satu botol plastik berdiameter $3,5 \times 4 \mathrm{~cm}$ yang telah diisi dengan pakan buatan modifikasi dari formulasi Poitout et al. (1972) dalam Saljoqi et al. (2015) ukuran 1 x 1 x $1 \mathrm{~cm}$.

Pengamatan perkembangan larva $S$. litura dilakukan setiap hari dan dilakukan pengukuran suhu dan kelembapan ruangan pemeliharaan dengan menggunakan higrotermometer. Setelah larva $S$. litura berubah menjadi pupa, kemudian pupa dimasukkan ke dalam toples kaca berukuran diameter $14 \times 22 \mathrm{~cm}$ yang alasnya diberi 3 lembar tisu. Selanjutnya, dimasukkan potongan kertas buram ukuran $15 \times 15 \mathrm{~cm}$ sebanyak 3 lembar yang dilipat dan diletakkan dalam posisi berdiri untuk tempat imago betina $S$. litura bertelur. Toples kaca ditutup menggunakan kain kasa. Jumlah pupa yang dimasukkan ke dalam satu toples kaca berjumlah 20 pupa. Pupa yang telah menjadi imago diberi pakan berupa larutan madu dengan aqudest $10 \%$ yang ditambah $0,59 \mathrm{~g}$ asam askorbat. Pemberian pakan pada imago dilakukan dengan cara menyerapkan larutan madu $10 \%$ pada gulungan kapas, lalu gulungan kapas tersebut digantung di tutup toples kaca, yakni kain kasa menggunakan karet gelang.

\section{- Ekstraksi}

Metode ekstraksi daun $A$. squamosa dan rimpang C. domestica mengacu pada Kamaraj et al. (2011) dengan modifikasi. Modifikasi tersebut meliputi proses pengeringan daun dan proses penguapan pelarut sampai menjadi ekstrak. Daun $A$. squamosa dan rimpang $C$. domestica dicuci dengan air mengalir (air keran) sampai bersih. Daun $A$. squamosa dan rimpang C. domestica tersebut diletakkan di dalam ruangan tanpa terkena paparan sinar matahari secara langsung dengan suhu $26-29^{\circ} \mathrm{C}$ dan dikeringanginkan menggunakan kipas angin selama 26 hari. Setelah 26 hari, pengeringan daun $A$. squamosa dan rimpang $C$. domestica dilanjutkan dengan cara memasukkan sampel ke dalam oven Memmert pada suhu $40^{\circ} \mathrm{C}$ selama 24 jam. Daun dan rimpang yang telah kering, lalu dihaluskan dengan blender (tanpa air) sampai menjadi serbuk. Serbuk daun $A$. squamosa dan rimpang $C$. domestica diekstraksi menggunakan pelarut etanol $96 \%$ dengan teknik maserasi. Larutan ekstrak yang telah disaring lalu dimasukkan ke dalam mangkuk kaca kapasitas $1 \mathrm{~L}$ lalu ditutup menggunakan aluminium foil yang diberi lubang untuk mengeluarkan uap pelarut. Selanjutnya mangkuk kaca yang berisi larutan ekstrak dimasukkan ke dalam almari kaca ukuran $70 \times 70 \times 70 \mathrm{~cm}$ yang di dalamnya terdapat kipas angin berdiameter $30 \mathrm{~cm}$. Ekstrak yang diperoleh 
dimasukkan ke dalam gelas kaca diameter $3 \times 6 \mathrm{~cm}$ lalu ditutup menggunakan aluminium foil yang dilapisi plastik wrap.

\section{- Uji pendahuluan}

Uji pendahuluan dilakukan untuk menentukan kisaran konsentrasi yang digunakan pada uji efektivitas. Pada uji pendahuluan digunakan lima konsentrasi pengenceran dari larutan stok campuran ekstrak uji, yakni 10.000, 1.000, 100, 10, dan 1 ppm, serta menggunakan kontrol negatif, yakni larutan etanol $1 \%$ dan kontrol positif berupa insektisida biologis Dipel WP 5.000 ppm. Uji pendahuluan dilakukan dengan empat ulangan.

Metode pengujian yang dilakukan adalah pencelupan pakan ke dalam campuran ekstrak uji yang mengacu pada metode yang dilakukan oleh Arivoli \& Tennyson (2012). Larva instar kedua dan ketiga $S$. litura mendapat perlakukan sama, yakni pemberian pakan yang telah direndam ke dalam campuran ekstrak uji. Uji pendahuluan dilakukan dengan empat ulangan. Pakan buatan dipotong dengan ukuran seragam yakni $1 \times 1 \times 1 \mathrm{~cm}$.

Potongan pakan buatan direndam ke dalam 14 glass jam berdiameter $6 \times 9 \mathrm{~cm}$ yang masing-masing berisi $100 \mathrm{~mL}$ larutan dengan konsentrasi yang berbeda, yakni $10.000,1.000,100,10$, dan 1 ppm insektisida Dipel WP 5.000 ppm, dan larutan etanol 1\% selama 60 menit. Langkah selanjutnya adalah potongan pakan buatan yang telah direndam lalu dimasukkan ke dalam botol plastik berdiameter 3,5 x 4 $\mathrm{cm}$.

Larva instar kedua dan ketiga $S$. litura yang digunakan untuk pengujian adalah larva instar hari pertama yang diperoleh dari pemeliharaan di Laboratorium Entomologi yang sebelumnya dipuasakan selama 4 jam. Satu larva dimasukkan ke dalam satu botol plastik berdiameter $3,5 \times 4 \mathrm{~cm}$ yang sudah berisi satu potong pakan buatan ukuran $1 \times 1 \times$ $1 \mathrm{~cm}$ (perlakuan) dengan menggunakan kuas lukis nomor 4. Pakan buatan diganti dengan pakan buatan yang baru (tanpa perlakuan) ukuran $1 \times 1 \times 1 \mathrm{~cm}, 24$ jam setelah pengujian sampai menjadi pupa.

Selama pengujian dan pengamatan kematian, temperatur dan kelembapan ruangan uji diukur tiga kali sehari pada pukul 08.00, 12.00, dan 17.00 WIB dengan menggunakan higrotermometer. Pengamatan kematian larva dilakukan 24, 48, 72, 96, dan 120 jam setelah pengujian. Kematian larva ditunjukkan dengan ciri larva yang tidak bergerak dan tidak berespons terhadap rangsang ketika tubuhnya disentuh dengan kuas lukis. Persentase mortalitas larva 24, 48, 72, 96, dan 120 jam setelah pengujian ditentukan menggunakan rumus persentase mortalitas yang mengacu pada Dono et al. (2008):

Mortalitas $(\%)=\frac{\text { Jumlah larva } S \text {. litura yang mati }}{\text { Jumlah larva } S \text {. litura yang diuji }} \times 100 \%$

\section{- Uji efektivitas}

Konsentrasi yang digunakan untuk uji efektivitas pada mortalitas larva instar kedua $S$. Litura, yakni $1.000,4.000,7.000$, dan 10.000 ppm serta instar ketiga S. Litura, yakni $9.000,10.000,11.000$, dan 12.000 ppm. Selain itu, digunakan kontrol negatif berupa larutan etanol $1 \%$ dan kontrol positif berupa insektisida Dipel WP 5.000 ppm.

Larva instar kedua dan ketiga $S$. litura yang digunakan untuk pengujian adalah larva instar kedua dan ketiga hari pertama yang diperoleh dari pemeliharaan di laboratorium yang sebelumnya dipuasakan selama 4 jam. Satu larva dimasukkan ke dalam satu botol plastik berdiameter $3,5 \times 4 \mathrm{~cm}$ yang sudah berisi satu potong pakan buatan berukuran $1 \mathrm{x}$ $1 \times 1 \mathrm{~cm}$ (perlakuan) dengan menggunakan kuas lukis nomor 4. Pakan buatan diganti dengan pakan buatan yang baru (tanpa perlakuan) berukuran $1 \times 1 \times 1 \mathrm{~cm}$ setelah 24 jam pengujian sampai menjadi pupa. Selama pengujian dan pengamatan kematian, temperatur dan kelembapan ruangan uji diukur tiga kali setiap hari, yakni pada pukul 07:00, 12:00, dan 17:00 WIB dengan menggunakan higrotermometer.

Pengamatan kematian larva instar kedua dan ketiga dilakukan 48 jam setelah pengujian. Kematian larva ditunjukkan dengan ciri larva yang tidak bergerak dan tidak berespons terhadap rangsang ketika tubuhnya disentuh dengan kuas lukis. Jumlah kematian larva dicatat. Persentase mortalitas larva 48 jam setelah pengujian ditentukan menggunakan rumus persentase mortalitas mengacu dari Dono et al. (2008), yakni:

Mortalitas $(\%)=\frac{\text { Jumlah larva } S \text {. litura yang mati }}{\text { Jumlah larva } S . \text { litura yang diuji }} \times 100 \%$

Apabila pada kontrol negatif terdapat larva S. litura yang mati kurang dari $20 \%$, maka data mortalitas dilakukan koreksi menggunakan rumus Abbot mengacu pada Dono et al. (2008), yakni:

$$
\mathrm{Pt}(\%)=\frac{\mathrm{Po}-\mathrm{Pc}}{100-\mathrm{Pc}} \times 100 \%
$$

Keterangan:

$\mathrm{Pt}=$ Persentase mortalitas larva $S$. litura yang telah dikoreksi

Po = Persentase mortalitas larva $S$. litura karena perlakuan

$\mathrm{Pc}=$ Persentase mortalitas larva $S$. litura pada kontrol

\section{Analisis Data}

Data yang diperoleh disajikan secara deskriptif dalam bentuk Tabel maupun Grafik. Pengolahan dan analisis data menggunakan program SPSS 21 . Analisis statistik yang digunakan adalah: a) Analisis ANOVA digunakan untuk mengetahui perbedaan efektivitas konsentrasi campuran ekstrak uji pada larva instar kedua dan ketiga S. litura (Gomez \& Gomez 2010), b) Jika nilai probability < 0,05 maka digunakan 
uji lanjut Duncan Multiple Range Test (DMRT) untuk mengetahui beda nyata efektivitas tiap konsentrasi campuran ekstrak uji (Gomez \& Gomez 2010). Efektivitas campuran ekstrak uji pada larva instar kedua dan ketiga $S$. litura dilihat berdasarkan kelompok perlakuan campuran ekstrak uji yang menyebabkan pengaruh yang sama pada rerata kematian dengan kelompok kontrol positif, dan c) Analisis probit digunakan untuk mengetahui nilai $\mathrm{LC}_{50}$ dan $\mathrm{LC}_{90}$ campuran ekstrak uji pada larva S. litura (Finney 1971).

\section{HASIL DAN PEMBAHASAN}

Hasil uji pendahuluan menunjukkan bahwa konsentrasi 1 , 10, dan 100 ppm tidak menyebabkan kematian pada semua fase larva sehingga ketiga konsentrasi tersebut tidak digunakan pada uji efektivitas. Kisaran konsentrasi campuran ekstrak uji pada uji pendahuluan yang menyebabkan kematian $10-90 \%$ larva adalah konsentrasi $1.000-10.000 \mathrm{ppm}$ yang seperti terlihat pada Tabel 1. Berdasarkan hasil tersebut maka ditentukan kisaran konsentrasi yang digunakan sebagai patokan konsentrasi untuk uji efektivitas larva instar kedua, yakni 1.000, 4.000, 7.000, dan $10.000 \mathrm{ppm}$, serta untuk instar ketiga, yakni $9.000,10.000,11.000$, dan 12.000 ppm.

\section{Uji Efektivitas}

Konsentrasi yang digunakan untuk uji efektivitas dibuat berdasarkan hasil uji pendahuluan sehingga konsentrasi 1.000-10.000 ppm digunakan sebagai acuan untuk membuat empat konsentrasi baru pada uji efektivitas. Oleh karena itu, pada uji efektivitas digunakan empat konsentrasi baru untuk pengujian larva instar kedua, yakni 1.000, 4.000, 7.000, dan $10.000 \mathrm{ppm}$ dan larva instar ketiga, yakni 9.000, $10.000,11.000$, dan $12.000 \mathrm{ppm}$, serta larutan etanol $1 \%$ sebagai kontrol negatif dan insektisida Dipel WP $5.000 \mathrm{ppm}$ sebagai kontrol positif. Persentase rerata kematian larva instar kedua $S$. litura tersaji pada Tabel 2.

Data hasil pengamatan kematian larva instar kedua S. litura dianalisis statistik dengan ANOVA. Hasil statistik menunjukkan bahwa semua kelompok perlakuan menyebabkan perbedaan jumlah kematian larva uji dengan kelompok kontrol negatif dan setiap kelompok perlakuan yang berbeda menyebabkan perbedaan jumlah kematian larva uji. Perlakuan dengan konsentrasi 10.000 ppm menyebabkan kematian larva uji sama dengan kelompok kontrol positif, yang berarti senyawa kimia campuran ekstrak uji pada konsentrasi 10.000 ppm menyebabkan tingkat kematian yang sama dengan Insektisida Dipel WP $5.000 \mathrm{ppm}$. Persentase rerata kematian larva instar ketiga S. litura tersaji pada Tabel 3.

Data hasil pengamatan kematian larva instar ketiga S. litura dianalisis statistik dengan ANOVA. Hasil statistik menunjukkan bahwa semua kelompok perlakuan menyebabkan perbedaan jumlah kematian larva uji dengan kelompok kontrol negatif dan setiap kelompok perlakuan yang berbeda menyebabkan perbedaan jumlah kematian larva uji. Kelompok perlakuan dengan konsentrasi 12.000 ppm menyebabkan kematian larva uji tidak berbeda nyata dibandingkan dengan kelompok kontrol positif, yang berarti senyawa kimia campuran ekstrak uji pada konsentrasi $10.000 \mathrm{ppm}$ menyebabkan tingkat

Tabel 2 Analisis statistik kematian larva instar kedua Spodoptera litura F. 48 jam pengujian campuran ekstrak uji

\begin{tabular}{cc}
\hline $\begin{array}{c}\text { Kelompok perlakuan/ } \\
\text { Konsentrasi (ppm) }\end{array}$ & $\begin{array}{c}\text { Rerata kematian }(\%) \pm \\
\text { standar deviasi }\end{array}$ \\
\hline Larutan etanol 1\% & $0 \pm 0,00^{\mathrm{a}}$ \\
1.000 & $17 \pm 0,58^{\mathrm{b}}$ \\
4.000 & $43 \pm 0,58^{\mathrm{c}}$ \\
7.000 & $60 \pm 1,00^{\mathrm{d}}$ \\
10.000 & $87 \pm 0,58^{\mathrm{e}}$ \\
Dipel WP $(5.000)$ & $97 \pm 0,58^{\mathrm{e}}$ \\
\hline
\end{tabular}

Keterangan: Angka yang diikuti huruf yang berbeda pada kolom yang sama menunjukkan berbeda nyata $\left({ }^{* *}\right)$

Tabel 3 Analisis statistik kematian larva instar ketiga Spodoptera litura F. 48 jam setelah pengujian campuran ekstrak uji

\begin{tabular}{lc}
\hline $\begin{array}{c}\text { Kelompok perlakuan/ } \\
\text { konsentrasi }(\mathrm{ppm})\end{array}$ & $\begin{array}{c}\text { Rerata kematian }(\%) \pm \\
\text { standar deviasi }\end{array}$ \\
\hline Larutan etanol $1 \%$ & $0 \pm 0,00^{\mathrm{a}}$ \\
9.000 & $23 \pm 0,58^{\mathrm{b}}$ \\
10.000 & $43 \pm 0,58^{\mathrm{c}}$ \\
11.000 & $60 \pm 0,58^{\mathrm{d}}$ \\
12.000 & $70 \pm 1,00^{\mathrm{e}}$ \\
Dipel WP $(5.000)$ & $80 \pm 0,00^{\mathrm{e}}$ \\
\hline
\end{tabular}

Tabel 1 Hasil pengamatan uji pendahuluan campuran ekstrak uji pada larva instar kedua dan ketiga Spodoptera litura F. setelah 48 jam pengujian

\begin{tabular}{lcc}
\hline \multirow{2}{*}{ Kelompok perlakuan/konsentrasi $(\mathrm{ppm})$} & \multicolumn{2}{c}{ Rerata kematian (\%) pada fase larva } \\
\cline { 2 - 3 } & Instar kedua & Instar ketiga \\
\hline Larutan etanol 1\% & 0 & 0 \\
1 & 0 & 0 \\
10 & 0 & 0 \\
100 & 0 & 10 \\
1.000 & 18 & 45 \\
10.000 & 83 & 83 \\
Dipel WP (5.000) & 95 & \\
\hline
\end{tabular}


kematian yang tidak berbeda nyata dibandingkan dengan Insektisida Dipel WP 5.000 ppm.

Peningkatan persentase kematian larva instar kedua dan ketiga $S$. litura berbanding lurus dengan peningkatan konsentrasi campuran ekstrak uji sehingga semakin tinggi konsentrasi campuran ekstrak uji maka semakin banyak jumlah kematian larva. Hasil penelitian ini sejalan dengan hasil penelitian Rajguru \& Sharma (2012) yang menyatakan bahwa peningkatan konsentrasi campuran ekstrak daun $A$. squamosa dan $B$. thuringiensis berbanding lurus dengan jumlah kematian larva $S$. litura setelah 1-6 hari pengujian. Hal ini kemungkinan bahwa semakin tinggi konsentrasi campuran ekstrak uji maka semakin tinggi pula senyawa aktif yang bersifat toksik. Hal ini didukung pula oleh pernyataan Amelia (2015) bahwa semakin tinggi konsentrasi ekstrak daun $S$. mahagoni maka semakin tinggi pula jumlah kematian larva Aedes aegypti.

Variasi individu dalam satu populasi serangga uji menyebabkan perbedaan pada kematian dan ketahanan hidup larva setelah terkena pemaparan campuran ekstrak daun $A$. squamosa dan rimpang $C$. domestica, yaitu pada konsentrasi 1.000 ppm dapat menyebabkan kematian larva instar kedua sebanyak $17 \%$ dan sebanyak $83 \%$ tidak mengalami kematian (Tabel 2). Adanya variasi genetik pada individu dalam suatu populasi menyebabkan perbedaan respons individu tersebut terhadap suatu respons lingkungan, misalnya paparan senyawa toksik (Campbell et al. 2004). Variasi genetik menyebabkan ketahanan tubuh serangga terhadap suatu senyawa toksik berbeda (Hasibuan 2015). Serangga memiliki kemampuan bereproduksi dan menghasilkan keturunan dalam jumlah yang banyak dan dalam waktu singkat sehingga serangga memiliki keragaman genetik yang besar. Oleh karena itu, ketika ada suatu paparan senyawa toksik dengan konsentrasi tertentu pada suatu populasi serangga, terdapat individu yang mati dan ada pula yang mampu bertahan hidup. Menurut Hasibuan (2015), terdapatnya individu yang dapat bertahan hidup setelah adanya pemaparan senyawa toksik ialah karena individu tersebut mampu memproduksi enzim detoksifikasi yang dapat menetralkan senyawa toksik. Ariesyadi dan Soemirat (2015) mengemukakan bahwa konsentrasi senyawa toksik yang diberikan pada individu dalam suatu populasi menyebabkan kematian dan menimbulkan efek subletal pada setiap individu.

Nilai LC 50 (Lethal concentration) campuran ekstrak uji yang dibutuhkan untuk membunuh larva instar kedua dan ketiga lebih rendah jika dibandingkan dengan penelitian Selvaraj et al. (2010) serta Balfas dan Willis (2009). Penelitian Selvaraj et al. (2010) menyatakan bahwa ekstrak biji $A$. squmosa pada larva S. litura memiliki LC 5025.750 ppm dan hasil penelitian Balfas \& Wilis (2009) menyatakan bahwa ekstrak rimpang $C$. domestica pada larva $S$. litura memiliki $\mathrm{LC}_{20}$ 10.000 ppm. Hal ini menunjukkan bahwa campuran ekstrak uji memiliki lebih banyak jenis metabolit sekunder yang bersifat sinergis sehingga konsentrasi campuran ekstrak uji yang digunakan untuk membunuh larva $S$. litura lebih rendah daripada menggunakan ekstrak tunggal daun $A$. squamosa atau rimpang $C$. domestica.

Senyawa metabolit sekunder yang bersifat sinergis terdapat pada daun $A$. squamosa dan rimpang $C$. domestica. Menurut Barve (2011), kandungan senyawa metabolit sekunder pada daun $A$. squamosa adalah saponin, flavonoid, tannin, dan alkaloid. Penelitian Raj et al. (2009) dan Mulyani et al. (2013) menunjukkan bahwa daun $A$. squamosa mengandung senyawa metabolit sekunder, yaitu flavonoid, saponin, triterpenoid, steroid, alkaloid, dan kumarin. Menurut Jaswanth et al. (2002), senyawa bioaktif yang diduga sebagai bahan utama insektisida nabati pada daun $A$. squamosa adalah senyawa acetogenin dari kelompok senyawa alkaloid. Rimpang $C$. domestica memiliki kandungan senyawa, yakni $28 \%$ glukosa, $12 \%$ fruktosa, $8 \%$ protein, vitamin $\mathrm{C}$, kalium kurkuminoid, dan $1,5 \%$ minyak atsiri yang terdiri atas $60 \%$ keton seskuiterpen, 25\% zingiberina, dan 25\% kurkumin beserta turunannya (Rismunandar, 1998). Menurut Dutta (2015), metabolit sekunder pada rimpang $C$. domestica adalah senyawa golongan alkaloid, flavonoid, terpenoid, fenol, tanin, dan saponin.

Campuran dua ekstrak tanaman yang bersifat sinergis dapat meningkatkan efektivitas suatu insektisida nabati pada kematian serangga hama dan vektor penyakit daripada menggunakan ekstrak tunggal (Vastrad et al., 2002; Koul and Walia, 2009). Hasil penelitian ini sejalan dengan hasil penelitian Rajguru and Sharma (2012) yang menyimpulkan bahwa perlakuan dengan campuran ekstrak daun $A$. squamosa dan $B$. thuringiensis membutuhkan konsentrasi yang lebih rendah daripada menggunakan perlakuan tunggal untuk membunuh larva $S$. litura.

Uji pendahuluan dan efektivitas dilakukan dengan cara memberi pakan buatan pada larva $S$. litura yang telah direndam ke dalam suatu larutan campuran ekstrak uji dengan konsentrasi tertentu. Larva memakan pakan sehingga metabolit sekunder yang bersifat toksik tersebut ikut termakan oleh larva. Senyawa aktif ekstrak daun $A$. squamosa dan rimpang $C$. domestica merupakan racun perut bagi larva $S$. litura. Menurut Tjahyono et al. (2005), insektisida racun perut merupakan insektisida yang merusak bagian tubuh serangga setelah masuk melalui mulut dan merusak saluran pencernaan. Campuran ekstrak uji tidak langsung mematikan serangga, tetapi mati secara perlahan. Pada penelitian ini, jumlah kematian larva terbanyak pada semua kelompok uji dan kontrol positif terjadi 48 jam setelah pengujian campuran ekstrak uji. Hasil penelitian ini sama dengan hasil penelitian Rajguru \& Sharma (2012), Balfas \& Willis (2009), Selvaraj et al. (2010) yang menggunakan ekstrak tanaman sebagai pengendali larva $S$. litura dengan jumlah kematian terbanyak 24 jam setelah pengujian. 
Berdasarkan pengamatan visual, larva $S$. litura yang diberi perlakuan campuran ekstrak menunjukkan gejala larva mati dengan ukuran tubuh yang terlihat lebih kecil kemudian integumen larva mengering dan akhirnya mati (Gambar 1). Hal ini sama dengan hasil penelitian Dono et al. (2008) yang menyatakan bahwa ekstrak biji Barringtonia asiatica menyebabkan larva $C$. pavonana mengalami kematian dengan ciri ukuran larva lebih kecil dari ukuran larva normal. Sumber yang sama menyatakan kematian larva karena paparan suatu ekstrak tanaman diduga disebabkan oleh senyawa saponin dan alkaloid yang merupakan komponen toksik dari ekstrak yang diaplikasikan, yang menyebabkan keracunan dan gangguan metabolisme tubuh sehingga aktivitas hidup serangga menjadi terhambat dan menyebabkan kematian secara perlahan.

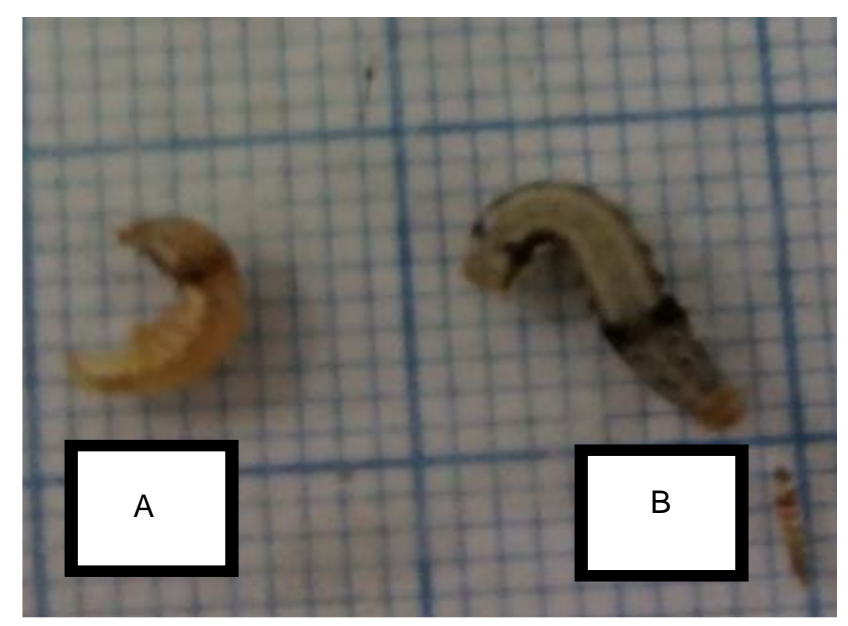

Gambar 1 Larva Spodoptera litura F. a) kelompok pengujian campuran ekstrak uji yang menunjukkan perubahan warna larva menjadi lebih kuning, permukaan integumen larva mengering, dan ukuran larva tidak bertambah b) kelompok kontrol negatif dengan warna larva mulai kehitaman dan ukuran larva bertambah besar setiap hari (skala $1 \mathrm{~mm}$ ) (koleksi pribadi).

Nilai $L_{50}$ dan $L C_{90}$

Instar kedua

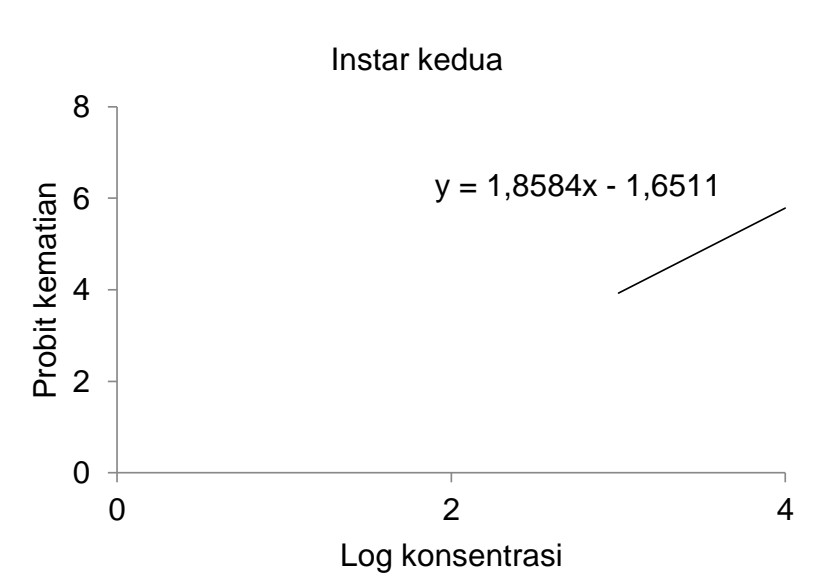

\section{Nilai LC $_{50}$ dan LC $_{90}$}

Penentuan efektivitas campuran ekstrak uji berupa nilai LC ditentukan dengan menggunakan analisis Probit angka kematian larva yang disebabkan oleh campuran ekstrak tersebut. Nilai LC menyatakan konsentrasi campuran ekstrak uji yang menyebabkan persentase kematian larva $S$. litura. Semakin rendah nilai LC maka campuran ekstrak uji semakin efektif karena dengan konsentrasi yang rendah menyebabkan kematian larva yang tinggi. Garis persamaan regresi linear log konsentrasi campuran ekstrak uji dengan probit kematian larva instar kedua dan ketiga $S$. litura dapat dilihat pada Gambar 2.

Persamaan garis regresi linear pada pengujian larva instar kedua dan ketiga secara berurutan adalah $y=1,8584 x-1,6511$ dan $y=9,8356 x-34,552$. Kedua persamaan ini diperoleh dari garis regresi linear yang terbentuk dari perpotongan empat titik log konsentrasi yang digunakan pada saat pengujian larva instar kedua dan ketiga dengan probit kematian larva instar kedua dan ketiga yang dilihat dari tabel persentase probit kematian (Finney, 1971). Berdasarkan persamaan garis regresi linear tersebut, maka ditentukan nilai $\mathrm{LC}_{50}$ dan LC $_{90}$ dengan cara memasukkan persentase kematian probit ke dalam nilai y. Nilai $\mathrm{LC}_{50}$ dan $\mathrm{LC}_{90}$ campuran ekstrak uji pada mortalitas larva instar kedua dan ketiga S. litura 48 jam setelah pengujian tersaji pada Tabel 4.

Nilai LC $_{50}$ dan LC $_{90}$ larva instar kedua lebih rendah daripada larva instar ketiga. Nilai LC $_{50}$ dan LC 90 larva instar kedua adalah $5.252 \mathrm{ppm}$ dan $11.124 \mathrm{ppm}$, sedangkan pada larva instar ketiga adalah $10.559 \mathrm{ppm}$ dan $13.638 \mathrm{ppm}$. Larva instar kedua lebih rentan dibandingkan larva instar ketiga 48 jam setelah pengujian campuran ekstrak uji. Hal ini bisa dilihat dari LC50 larva instar kedua yang lebih rendah daripada instar ketiga. Hasil penelitian ini sama dengan hasil penelitian Amelia (2015) yang menyatakan bahwa nilai $\mathrm{LC}_{50}$ dan $\mathrm{LC}_{90}$ ekstrak daun Swietenia mahagoni pada larva instar kedua lebih rendah daripada instar ketiga Aedes aegypti.

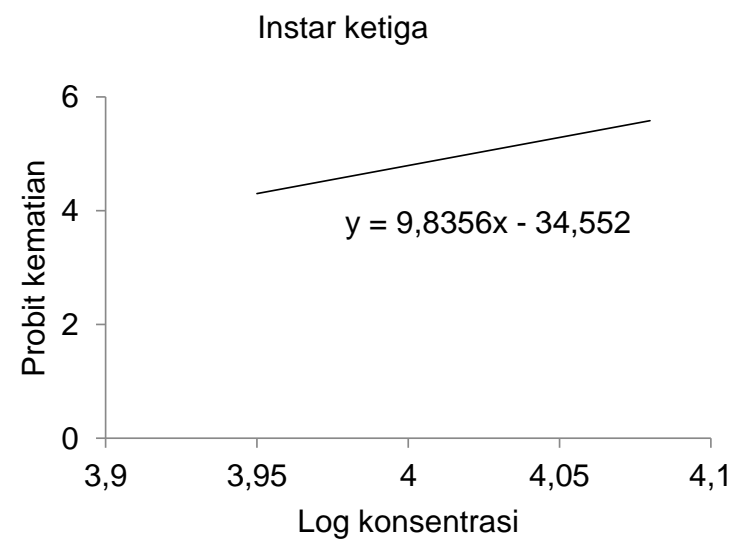

Gambar 2 Garis persamaan regresi linear log konsentrasi campuran ekstrak uji dengan probit kematian larva Spodoptera litura $\mathrm{F}$. 
Individu yang lebih muda memiliki aktivitas makan yang lebih banyak dibandingkan dengan individu yang lebih dewasa dalam hal proporsi makan dibandingkan bobot tubuh (Hayes 2011). Oleh karena itu, jika makanan kedua individu diberi zat toksik dengan konsentrasi sama, individu muda menerima jumlah racun yang lebih banyak dibandingkan dengan individu dewasa sehingga efek yang ditimbulkan oleh senyawa tosik tersebut lebih banyak pada individu muda daripada individu tua. Persentase rerata larva instar kedua dan ketiga yang mengalami kematian setelah pemaparan campuran ekstrak uji dengan konsentrasi yang sama dapat dilihat pada Tabel 5 .

Menurut Goulson et al. (1995) sistem pertahanan tubuh pada serangga dengan umur larva yang lebih tua lebih kuat daripada umur larva yang lebih muda, serta dibutuhkan zat toksik dengan konsentrasi lebih besar untuk membunuh serangga dengan fase perkembangan yang lebih tua.

\section{KESIMPULAN}

Campuran ekstrak uji efektif pada mortalitas larva instar kedua dan ketiga serta lebih efektif pada larva instar kedua daripada larva instar ketiga S. litura. LC 50 campuran ekstrak uji pada larva instar kedua dan ketiga secara berurut adalah 5.252 ppm dan 10.559 ppm serta $\mathrm{LC}_{90}$ secara berurut adalah 11.124 ppm dan $13.638 \mathrm{ppm}$.

\section{UCAPAN TERIMA KASIH}

Penulis mengucapkan terima kasih kepada Dekan Fakultas Biologi UGM atas bantuan dana penelitian BOPTN Tahun 2016 Fakultas Biologi UGM.

\section{DAFTAR PUSTAKA}

Abdinegara. 2003. Penggunaan Analisis Probit Untuk Pendugaan Tingkat Kepekaan Populasi Spodoptera exigua Terhadap Deltametrin di Daerah Istimewa Yogyakarta. Informatika Pertanian. 12: $1-8$.

Amelia TRN. 2015. Efektivitas Ekstrak Air dan Etanol Daun Mahoni (Swietenia mahagoni (L.) Jacq) Terhadap Larva dan Imago Aedes aegypti L. [Tesis]. Yogyakarta (ID): Universitas Gadjah Mada. pp. 42-43 .

Arivoli S, Tennyson S. 2012. Antifeedant Activity of Plant Extract Againts Spodoptera litura (Fab.) (Lepidoptera: Noctuidae). American-Eurasian Journal of Agricultural \& Environmental Sciences 12 (6): 764-768.

Balfas R, Willis M. 2009. Pengaruh Ekstrak Tanaman Obat Terhadap Mortalitas da Kelangsungan Hidup
Tabel 4 Nilai LC $_{50}$ dan LC $_{90}$ campuran ekstrask uji pada mortalitas larva Spodoptera litura F.

\begin{tabular}{ccc}
\hline $\begin{array}{c}\text { Fase } \\
\text { Perkembangan }\end{array}$ & LC $_{50}(\mathrm{ppm})$ & LC $_{90}(\mathrm{ppm})$ \\
\hline Instar kedua & 5.252 & 11.124 \\
Instar ketiga & 10.559 & 13.638 \\
\hline
\end{tabular}

Tabel 5 Persentase rerata larva instar kedua dan ketiga yang mengalami kematian setelah pemaparan campuran ekstrak uji dengan konsentrasi 10.000 ppm

\begin{tabular}{ccc}
\hline $\begin{array}{c}\text { Kelompok } \\
\text { perlakuan/ } \\
\text { Konsentrasi } \\
(\mathrm{ppm})\end{array}$ & $\begin{array}{c}\text { Rerata kematian } \\
\text { larva instar } \\
\text { kedua }(\%)\end{array}$ & $\begin{array}{c}\text { Rerata kematian } \\
\text { larva instar } \\
\text { ketiga (\%) }\end{array}$ \\
\hline 10.000 & 87 & 43 \\
\hline
\end{tabular}

Spodoptera litura F. (Lepidoptera: Noctuidae). Buletin Penelitian Tanaman Rempah dan Obat. 20(2): 148-156.

Barve D, Pandey N. 2011. Phytochemical and Pharmacological Review on Annona squamosa Linn. International Journal of Research in Pharmaceutical and Biomedical Sciences. 2(4). 1404-1412

Campbell NA, Reece JB, Mitchell L. G. 2004. Biologi. Jakarta (ID): Penerbit Erlangga. pp. 22-26

Dadang, Fitriasari ED, Prijono D. 2011. Field Efficacy of Two Botanical Insecticide Formulations Againts Cabbage Insect Pest, Crocidolomia pavonana (F.) (Lepidoptera: Pyralidae) and Plutella xylostella (I.) (lepidoptera: Yponomeutidae). Journal of the International Society for Southeast Asian Agricultural Sciences. 17(2): 38-47.

Dono D, Hidayat S, Nasahi C, Anggraini E. Pengaruh Ekstrak Biji Barringtonia asiatica L. (Kurz) (Lecythidaceae) Terhadap Mortalitas Larva dan fekunditas Crocidolomia pavonana F. (Lepidoptera: Pyralidae). Jurnal Agrikultura. 19(1): 5-14. https:// doi.org/10.24198/agrikultura.v19i1.601

Dutta B. 2015. Study of Secondary metabolite Constituents and Curcumin Contents of Six Different Species of Genus Curcuma. Journal of Medicinal Plants Studies. 3(5): 116-119.

Felsot AS, Racke K. D. 2007. Chemical Pest Control Technology: Benefit, Disadvantages, and Continuing Roles in Crop Production Systems, In Crop Protection Products for Organic Agriculture Enviromental, Health, and Efficacy Assesment. American Chemical Society Symposium Series, American Chemical Society. Washington DC: 1-18. https://doi.org/10.1021/bk-2007-0947.ch001

Finney DJ. 1971. Probit Analysis. Third edition. London (EN): Cambridge University Press pp. 25. 
Gomez KA, Gomez AA. 2010. Prosedur Statistik Untuk Penelitian Pertanian. Penerjemah Endang Sjamsuddin dan Justika S. Baharsjah. Jakarta (ID): Penerbit Universitas Indonesia. pp 8-18.

Goulson D, Hails RS, William T, Hirst ML, Vasconcelos SD. 1995. Tranmission Dynamics of $A$ virus in $A$ Stage-Structured Insect Population. Ecology. 76(2): 392-401. https://doi.org/10.2307/1941198

Hasibuan, R. 2015. Insektisida Organik Sintetik dan Biorasional. Yogyakarta (ID): Plantaxia. pp. 10

Hayes WJ. 2010. Third Edition. Hayes Handbook of Pesticide Toxicology. San Diego (US): Academic Press

Jaswanth A, Raanathum P, Ruckman K. 2002. Evaluation of Mosquitocidal Activity of Annona squamosa Leaves Againts Filarial Vector osquito, Culex quinquefasciatus Say. Indian Journal of Experimental Biology. 40: 363-365.

Kalshoven LGE. 1981. The Pest of Crops In Indonesia. Revised By Van Der Laan. Jakarta (ID): PT Ichtiar Baru-Van Hoeve. Pp. 338-339.

Kandagal AS, Khetagoudar MC. 2013. Study on Larvicidal Activity of Weed Extracts Againts Spodoptera litura. Journal of Environmental Biology. 34: 253-257.

Koul O, Walia S. 2009. Comparing Impact of Plant Exstract and Pure Allelochemicals and Implications for Pest Control. Perspective in Agriculture, Vetrinary Science, Nutrition and Natural Resources. 49: 1-20.

Kumar AG, Sevarkodiyone SP. 2009. Effect of Seed Extract of Annona Squamosa L. and Lepidium sativum L. on The Pupal Develompent and reproductive Parameters of Tobacco Curworm Spodoptera litura (Fabricius). Hexapoda. 16(2): 132-135

Lee H, Shin W, Song C, Cho K, Ahn Y. 2001. Insecticidal Activities of ar-Turmerone Identified in Curcuma longa Rhizome againts Nilapavarta lugens (Homoptera: Delphacidae) and Plutella xylostella (Lepidoptera: Yponomeutidae). Journal of Asia-Pacific Entomology. 4(2): 181-185. https:// doi.org/10.1016/S1226-8615(08)60121-1

Liu SQ, Shi JJ, Cao H, Jia FB, Liu XQ, Shi GL. 2000. Survey of Pesticidal component in Plant. In: Entomology in China in 21st Century. Proceedings of 2000 Conference of Chinese Entomological Society Eds. Dianmo. Li Beijing. China. Science and Technique: 1098-1104.

Marwoto, Suharsono. 2008. Strategi dan Komponen Teknologi Pengendalian Ulat Grayak (Spodoptera litura Fabricius) Pada Tanaman Kedelai. Jurnal Litbang Pertanian. 27(4): 131-136.
Mulyaman S, Cahyaniati, Adam I, Mustofa T. 2000. Pengenalan Pestisida Nabati Tanaman Holtikultura. Jakarta (ID): Direktorat Perlindungan TanamanDepartemen Pertanian. pp. 24-38.

Mulyani M, Arifin B, Nurdin H. 2013. Uji Antioksidan dan Isolasi Senyawa metabolit Sekunder Dari Daun Srikaya (Annona squamosa L.). Jurnal Kimia Unand. 2(1): 6-12.

Rao MS, Rao CAR, Vennila S, Manimanjari D, Maheswari M, Venkateswarlu B. 2014. Estimation of Number of Generations of Spodoptera litura Fab. On Peanut in India Duting Near and Distant Future Climate Change Scenarios. Scientific Research and Essays. 9(7): 195-203. https://doi.org/ 10.5897/SRE2013.5783

Raj DS, Vennila JJ, Aiyavu C, Panneerselvam K. 2009. The Hepatoprotective Effect of Alcoholic Exstract of Annona squamosa Leaves on Experimentally induced Liver Injury in Swiss Albino Mice. International Journal of Integrative Biology. 5(3): 182-185.

Rajguru M, Sharma AN. 2012. Comparative efficacy of Plant Extracts alone and in Combination with Bacillus thuringiensis sub sp. kurstaki against Spodoptera litura Fab. Larvae. Journal of Biopesticides. 5(1): 81-86.

Rimbawani DD. 2009. Uji Ekstrak Daun dan Biji Srikaya (Annona squamosa) Terhadap Mortalitas Ulat Grayak (Spodoptera litura). [Skripsi]. Surabaya (ID): Institut Teknologi Sepuluh Nopember.

Rismunandar. 1998. Rempah-rempah: Komoditi Ekspor Indonesia. Bandung (ID): Penerbit Sinar Baru. pp. 141-143.

Selvaraj S, Adiroubane D, Ramesh V, Narayanan AL. 2010. Impact of Ecological Factors on Incidence and Development of Tobacco Cut Worm, Spodoptera litura Fabricius on Cotton. Journal of Biopesticides. 3(1): 043-046.

Shahout HA, Xu JM, Yao XM, Jia QD. 2011. Influence and Mechanism of Different Host Plants On The Growth, development and Fecundity of reproductive System of Common Cutworm Spodoptera litura (Fabricius) (Lepidoptera: Noctuidae). Asian Journal of Agricultural Science. 3 (4): 291-300.

Soemirat J, Ariesyady H. D. 2015. Toksikologi Lingkungan. Yogyakarta (ID): Gadjah Mada University Press. pp. 143-144.

Singh RN, Saratchandra B. 2005. The Development of Botanical Product with Special Reference to SeriEcosystem. Caspian Journal of Environmental Science. 3(1): 1-8.

Sutoyo, Wiriodmodjo B. 1997. Uji Insektisida Botani Daun Nimba (Azadirachta indica), Daun Pahitan (Eupatorium inulifolium) Dan Daun Kenikir (Tagetes 
spp) Terhadap Kematian Larva Spodoptera litura F. (Lepidoptera: Noctuidae) Pada Tanaman Tembakau. Prosiding Kongres Perhimpunan Entomologi Indonesia $V$ dan Symposium Entomologi. 317-321 p.

Suryaningsih E, Hadisoeganda WW. 2004. Pestisida Botani Untuk Mengendalikan Hama dan Penyakit Pada Tanaman Sayuran. Edisi I. Bandung (ID): Balai Penelitian Tanaman Sayuran. Pp. 19-26.

Tavares WS, Freitas, Silvia S, Grazziotti GH, Parente LML, Liao LM, Zanuncio JC. 2013. Ar-turmerone From Curcuma longa (Zingiberaceae) rhizomes and Effect on Sitophilus zeamais (Coleoptera: Curulionidae) and Spodoptera frugiperda (Lepidoptera: Noctuidae). Industrial Crops and
Product. 46: 158-264. https://doi.org/10.1016/ j.indcrop.2013.01.023

Tjahyono BR, Poerwanto, Sudarsono. 2005. Kamus Pertanian Umum. Jakarta (ID): Penebar Swadaya. Pp. 533.

Vastrad AS, Lingappa S, Basavanagoud K. Vegetable Oils as Synergist of Synthetic Pyrethroid Against Diamond Back Moth, Plutella xylostella L. (Yponomeutidae: Lepidoptera). Journal of the Entomological Research Society. 26: 285-290.

Zhang JS, Guan J, Yuang FQ, Liu HG, Cheng XJ, Li SP. 2008. Qualitative and Quantitative Analysis of Four Species of Curcuma rhizome Using Twice Development Thin Layer Chromatography. J. Pharmaceut. Biomed. 48: 1024-1028. https:// doi.org/10.1016/j.jpba.2008.07.006 